\title{
Activation of lamina propria $T$ cells induces crypt epithelial proliferation and goblet cell depletion in cultured human fetal colon
}

\author{
C M Evans, A D Phillips, J A Walker-Smith, T T MacDonald
}

\begin{abstract}
An organ culture model has been used to study the effects of $T$ cell activation in the human colon. Lamina propria $T$ cells in explant cultures of human fetal colon (11 to 23 weeks gestation) were activated in situ using pokeweed mitogen or an anti-CD3 monoclonal antibody, and compared with unstimulated controls. After three days of culture, there was a two to four-fold increase in crypt epithelial cell proliferation in $T$ cell stimulated explants of more than 15 weeks gestation, associated with a fall in crypt goblet cell numbers of up to 20 -fold. By three days, the surface epithelium of stimulated explants appeared thin with loss of goblet cells, and by day 7, severe and extensive mucosal damage was observed by light and electron microscopy. These changes did not occur in control cultures and explants deficient in $T$ cells (less than 16 weeks gestation), and were inhibited by cyclosporin $A$. These experiments indicate that the increase in epithelial cell proliferation and accompanying goblet cell depletion observed in colorectal crypts in chronic inflammatory bowel disease may be mediated by activated $T$ cells.
\end{abstract}

There is now considerable evidence that immunological mechanisms play a major role in

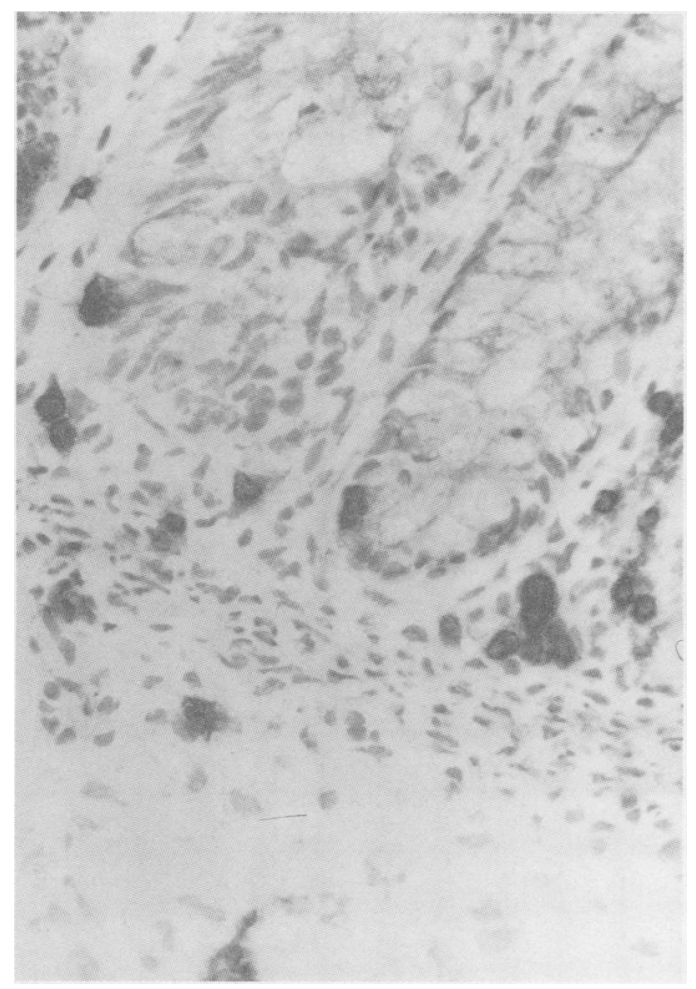

the pathogenetic changes which occur in chronic inflammatory bowel diseases such as ulcerative colitis and Crohn's disease. ${ }^{1-3}$ In particular, attention has focused on mucosal $\mathrm{T}$ cell immunoregulation in these conditions, and it has been suggested that $T$ cell activation is one of the mechanisms by which mucosal damage is mediated. ${ }^{+}$

In the present study, we have used an organ culture system to investigate the effects of $T$ cell activation in human large intestine, as an extension of our previous studies in the small bowel..$^{5-9}$ The presence of mucosal $\mathrm{T}$ cells in specimens of fetal colon of 11 to 23 weeks gestation was first confirmed using specific monoclonal antibodies. These cells were then stimulated in situ by treating cultured colonic explants with pokeweed mitogen or an anti-CD3 monoclonal antibody. The effects were monitored by light microscopy and ultrastructural examination. Cell proliferation in the cultures was assessed immunohistochemically using the monoclonal antibody $\mathrm{Ki} 67$.

\section{Methods}

COLLECTION OF TISSUE

These studies were carried out with the approva of the Ethical Committee of the City and Hackney Health Authority, and conformed to the Department of Health and Social Security guidelines on the use of human fetal tissue, as outlined in The use of fetuses and fetal material for research (HMSO SBN 11320478 7). Specimens of bowel were obtained from fetuses of 11 to 23 weeks gestation undergoing therapeutic abortion by curettage, and colon was differentiated from small bowel using the appendix as a landmark.

\section{IN VITRO ORGAN CULTURE}

The specimens were transported to the laboratory on ice in serum free CMRL-1066 tissue culture medium (Flow Laboratories Inc, McLean, VA, Canada), modified according to the technique described by Autrup et al..$^{10}$ The bowel was then placed in a Petri dish, and cut into segments 4-5 mm in length. Several of these specimens (day 0) were snap frozen in liquid nitrogen and stored at $-70^{\circ} \mathrm{C}$. The remaining segments were bisected longitudinally to expose the lumen, and trimmed into explants measuring $2 \mathrm{~mm} \times 2 \mathrm{~mm}$. The colonic explants so obtained were maintained in an organ culture system previously described by Menard and Arsenault." I: Between eight and 10 explants were placed in $7 \mathrm{ml}$ of the modified CMRL-1066 
medium in $5 \mathrm{~cm}$ diameter tissue culture dishes (Sterilin; Scientific Supplies Co Ltd, Vine Hill, London), and cultured at $37^{\circ} \mathrm{C}$ in a $95 \%$ oxygen: $5 \%$ carbon dioxide atmosphere for up to seven days. The morphological appearance of the explants was assessed daily by microscopy. After the desired period of culture, the explants were removed from each dish and placed on top of one another on filter paper to absorb excess moisture. They were then either snap frozen in liquid nitrogen and stored at $-70^{\circ} \mathrm{C}$, or fixed in formal saline for paraffin histology, or 3\% gluteraldehyde for electron microscopy.

\section{IMMUNOHISTOCHEMISTRY}

Immunohistochemical staining was carried out on $6 \mu \mathrm{m}$ frozen sections using the immunoperoxidase technique described elsewhere. ${ }^{13}$ Four monoclonal antibodies were used: Ki67 (Dako Ltd, High Wycombe, Bucks), which recognises a nuclear antigen common to all dividing human cells; anti-HLA-DR (Dako Ltd), as a measure of MHC Class II expression; the pan-T cell antibody anti-CD3 (anti-Leu 4, Becton Dickinson \& Co, Mountain View, CA, USA); and the IL2-receptor antibody anti-CD25 (TAC, Dako Ltd), a marker of T cell activation. All frozen sections were prepared so as to obtain a plane of section in which the maximal number of crypts possible were sectioned along their longitudinal axes in the majority of explants under study. Paraffin embedded sections were also prepared for standard histochemical staining with haematoxylin and eosin $(\mathrm{H} \& \mathrm{E})$ and Schiff's reagent (PAS stain).

\section{ELECTRON MICROSCOPY}

After fixation in 3\% gluteraldehyde, explants were processed for electron microscopy using standard techniques described elsewhere. ${ }^{14}$

\section{IN VITRO T CELL ACTIVATION}

In situ activation of mucosal $T$ cells within the colonic explants was achieved by adding one of two agents to the culture dishes: pokeweed mitogen (Flow Laboratories Inc), $50 \mu \mathrm{g} / 7 \mathrm{ml}$ culture medium, and anti-CD3 monoclonal antibody (Serotec Ltd, Kiddington, Oxford), $1 \mu \mathrm{g}$ / ml. Cyclosporin A (Sandoz Pharmaceuticals, Feltham, Middlesex), a potent suppressor of T cell function, ${ }^{15}$ was added to a number of culture dishes at concentrations of $0 \cdot 1-10 \mu \mathrm{g} / \mathrm{ml}$, either alone, or in the presence of pokeweed mitogen or anti-CD3 antibody.

\section{DATA ANAL YSIS}

Explants were assessed histologically after 0, 72, and 168 hours of culture. The number of $\mathrm{CD} 3+$ and CD25 + cells was noted per high power field (magnification $\times 400$ ), and the intensity of antiHLA-DR staining was graded from + to +++ . The intensity of epithelial cell division in the crypts of Lieberkühn was determined by counting the number of Ki67+ nuclei present in all well orientated, longitudinally sectioned crypts using the $\times 40$ objective on a Leitz Dialux microscope, as described previously. ${ }^{9}$ Only those crypts extending down as far as the muscularis mucosae in which the lumen could be clearly identified along the whole crypt length were used for counting purposes. At least 10 crypts were counted per frozen section, and each specimen was assessed blindly. In addition, the ratio of crypt goblet cells to epithelial cells was calculated for each group by comparing the total number of PAS staining cells (goblet cells) present to the total number of crypt cell nuclei. Finally, the appearance and thickness of the surface epithelium was assessed using electron microscopy after 24,48 , and 72 hours of culture.

\section{STATISTICAL ANALYSIS}

Cell counts from individual colonic specimens (CD3 + and CD25 + cell counts) are expressed as the mean $\pm 1 \mathrm{SD}$. All pooled data (Ki67+ and goblet cell counts) are expressed as the mean (for normally distributed data) or median (for nonparametric data), together with the $95 \%$ confidence interval $(95 \% \mathrm{CI})$ about the mean $/$ median. Differences in the number of goblet cells and proliferating crypt epithelial cells between $T$ cell activated explants and controls have been compared using the Mann-Whitney $U$ test. All statistical analyses were carried out on a Compaq microcomputer, using a CIA microcomputer program (British Medical fournal, London) for calculating the means, medians, and confidence intervals, ${ }^{16}$ and a Microstat statistical program (Ecosoft, Indianapolis) for performing the Mann-Whitney U tests.

\section{Results}

T CELLS IN HUMAN FETAL COLON

Immunohistochemistry showed the presence of $\mathrm{CD} 3+\mathrm{T}$ cells in the mucosa of day 0 specimens of human fetal colon from 14 weeks gestation onwards (Fig 1). In addition, the number of $\mathrm{CD} 3+$ cells in the lamina propria was found to increase with gestational age (Table I).

\section{T CELL ACTIVATION}

Activation of $\mathrm{T}$ cells in explants treated with pokeweed mitogen or anti-CD3 was confirmed by the appearance of CD25 + cells in the lamina propria after three days of culture (Table II), the numbers of which increased directly with gestational age. No CD25+ cells were observed in

TABLE I Mean number of mucosal CD3-positive cells per high power field $(H P F \times 400)$ in day 0 specimens of human fetal colon related to gestation age

\begin{tabular}{llc}
\hline $\begin{array}{l}\text { Fetal colon } \\
\text { (gestation/weeks) }\end{array}$ & $\begin{array}{l}\text { Specimens } \\
(\boldsymbol{n})\end{array}$ & $\begin{array}{l}\text { CD3+cells/HPF } \\
(S D)\end{array}$ \\
\hline 11 & 1 & 0 \\
12 & 1 & 0 \\
14 & 1 & $<1$ \\
15 & 1 & $5 \cdot 1(2 \cdot 4)$ \\
16 & 2 & $9 \cdot 8(4 \cdot 2)$ \\
17 & 2 & $11 \cdot 1(3 \cdot 9)$ \\
18 & 3 & $15 \cdot 6(3 \cdot 7)$ \\
19 & 2 & $18 \cdot 8(6 \cdot 1)$ \\
20 & 1 & $18 \cdot 5(3 \cdot 0)$ \\
23 & 1 & $25 \cdot 1(7 \cdot 4)$ \\
\hline
\end{tabular}


TABLE II Mean number of mucosal CD25-positive cells per high power field $(H P F \times 400)$ in explants from five human fetal colons of varying gestation cultured for three days after $T$ cell activation with anti-CD3 monoclonal antibody

\begin{tabular}{lll}
\hline $\begin{array}{l}\text { Fetal colon } \\
\text { (gestation/weeks) }\end{array}$ & $\begin{array}{l}\text { Specimens } \\
(n)\end{array}$ & $\begin{array}{l}\text { CD25+cells/HPF } \\
(S D)^{\star}\end{array}$ \\
\hline 14 & 1 & $<1$ \\
17 & 1 & $6 \cdot 2(2 \cdot 9)$ \\
19 & 1 & $1 \cdot 0(3 \cdot 3)$ \\
20 & 1 & $14 \cdot 5(2 \cdot 8)$ \\
23 & 1 & $29 \cdot 3(4 \cdot 1)$ \\
\hline
\end{tabular}

${ }^{\star}$ No CD25 + cells were observed in the mucosa of any control explants.

day 0 specimens, or in unstimulated day 3 controls. The number of CD3 + cells per high power field also increased in stimulated explants by day 3 compared with controls, indicating that $T$ cell proliferation had taken place (data not shown). In addition, class II expression (antiHLA-DR staining) was enhanced in the mucosa of $\mathrm{T}$ cell activated explants, correlating directly with increasing gestational age.

\section{CRYPT CELL PROLIFERATION}

The effect of $T$ cell activation on the rate of cell proliferation in the crypts of Lieberkühn is shown in Figure 2. The mean number of Ki67+ cells per crypt has been plotted against time using data pooled from 10 separate experiments involving colon of 16 to 20 weeks gestation. A two to four-fold increase in $\mathrm{Ki} 67$ staining was observed in the crypts of T cell activated explants by day 3 of culture compared with controls. The increase in cell proliferation rate was directly related to increasing gestational age, and also correlated directly with the number of lamina propria cells expressing CD25. The mean Ki67+ cell count per crypt in pokeweed mitogen stimulated explants (seven) was $49 \cdot 8$ (95\% CI $45 \cdot 3-$ $54 \cdot 3)$ compared with $23.5(95 \%$ CI $21 \cdot 0-25 \cdot 0)$ in controls $(\mathrm{p}<0.001)$, and $42.5(95 \%$ CI $39.3-$ $45 \cdot 6$ ) in anti-CD3 stimulated explants (three) compared with $20.2(95 \%$ CI $18.5-21.9)$ in controls $(p<0.001)$. The number of Ki67+ cells per crypt remained fairly constant in control explants by day 7 of culture, but fell in pokeweed mitogen and anti-CD3 treated explants to a level below that of controls.

GOBLET CELLS

There was a marked fall in crypt goblet cell numbers of up to 20 -fold in $\mathrm{T}$ cell-activated explants by day 3 of culture (Fig 3), which was maintained up to day 7 . In addition, many PAS positive goblet cells were observed in the culture medium surrounding stimulated explants. Figure 4 shows the change in the number of crypt goblet cells per 100 crypt cell nuclei with time for both stimulated and control explants, using data pooled from the same 10 experiments as Figure 2 . The crypt goblet cell per 100 crypt nuclei count fell from $32 \cdot 7(95 \%$ CI $31 \cdot 8-33 \cdot 7)$ to $10 \cdot 7(95 \%$.CI $8 \cdot 8-13 \cdot 7)$ in pokeweed stimulated explants by day $3(\mathrm{p}<0.001)$ and from $32.0(95 \%$ CI $30 \cdot 4-33 \cdot 6)$ to $8 \cdot 7(95 \%$ CI 5.3-12.1) in antiCD3 stimulated explants $(\mathrm{p}<0.001)$. In contrast, the respective day 3 control counts of 31.9 (95\% CI 30.3-33.6) and 30.5 (95\% CI 27.0-33.9) did not differ significantly from the day 0 values, and crypt goblet cell numbers were still well maintained in control explants by day 7 of culture.

\section{ULTRASTRUCTURE}

Electron microscopy showed thinning of the surface epithelium in T cell activated explants by day 3 of culture, associated with the presence of apoptosis in the epithelium and lamina propria (Fig 5b). These changes were not present in control explants, although some epithelial cell vacuolation and swelling of the intercellular spaces was observed (Fig 5a) as a direct consequence of normal absorption of water from the culture medium leading to tissue oedema in the absence of lymphatic and venous drainage. Such dilatation of the epithelial cell intercellular spaces has been described previously as a consequence of water absorption in the rat ileum under experimental conditions. ${ }^{17}$ Table III summarises the sequential morphological and ultrastructural changes observed in control and $\mathrm{T}$ cell-stimulated explants of 22 week gestation fetal colon cultured for three days.

\section{FETAL COLON OF DIFFERENT AGES}

The changes described above were only observed in colonic explants of 16 weeks or greater gestation. They did not occur in three experiments in which colonic specimens from 11,12 , and 14 week old fetuses were studied, presumably because of their paucity of T cells (Table I). One 15 week gestation specimen was found to contain $\mathrm{T}$ cells on day 0 staining (Table $\mathrm{I}$ ), but
Figure 2: Time course of the changes in the number of Ki67 + cells in the crypts of Lieberkuhn in cultured explants of human fetal colon following $T$ cell activation with pokeweed mitogen (seven specimens) or anti-CD3 monoclonal antibody (three specimens). Data pooled from 10 separate experiments using colon of 16-20 weeks gestation. The vertical bars above and below the points relate to the $95 \%$ confidence interval about the mean/ median.

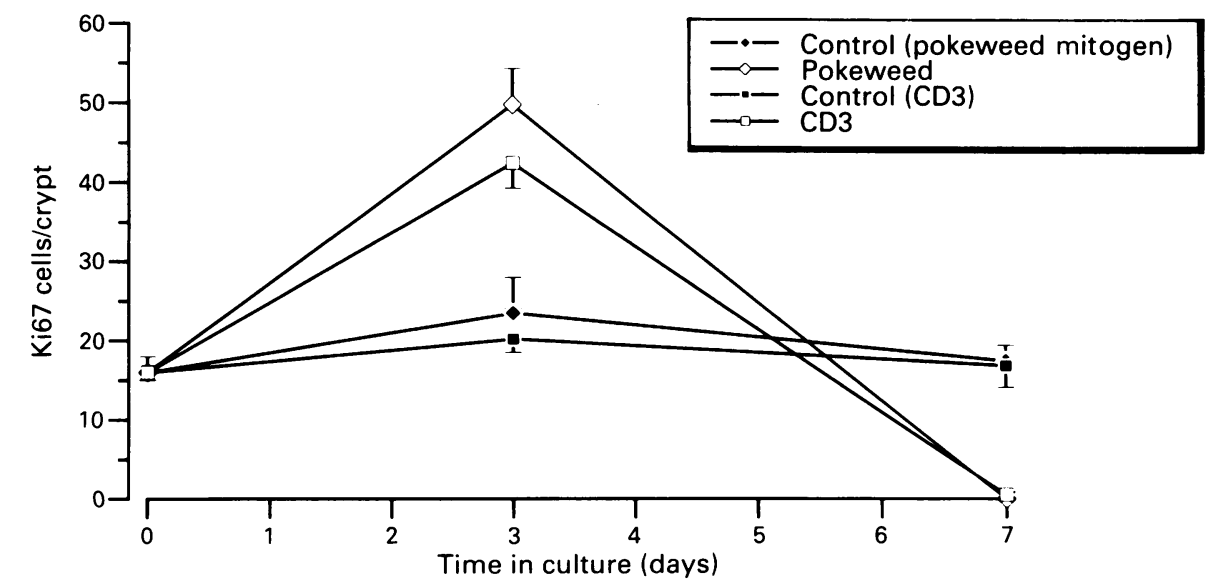



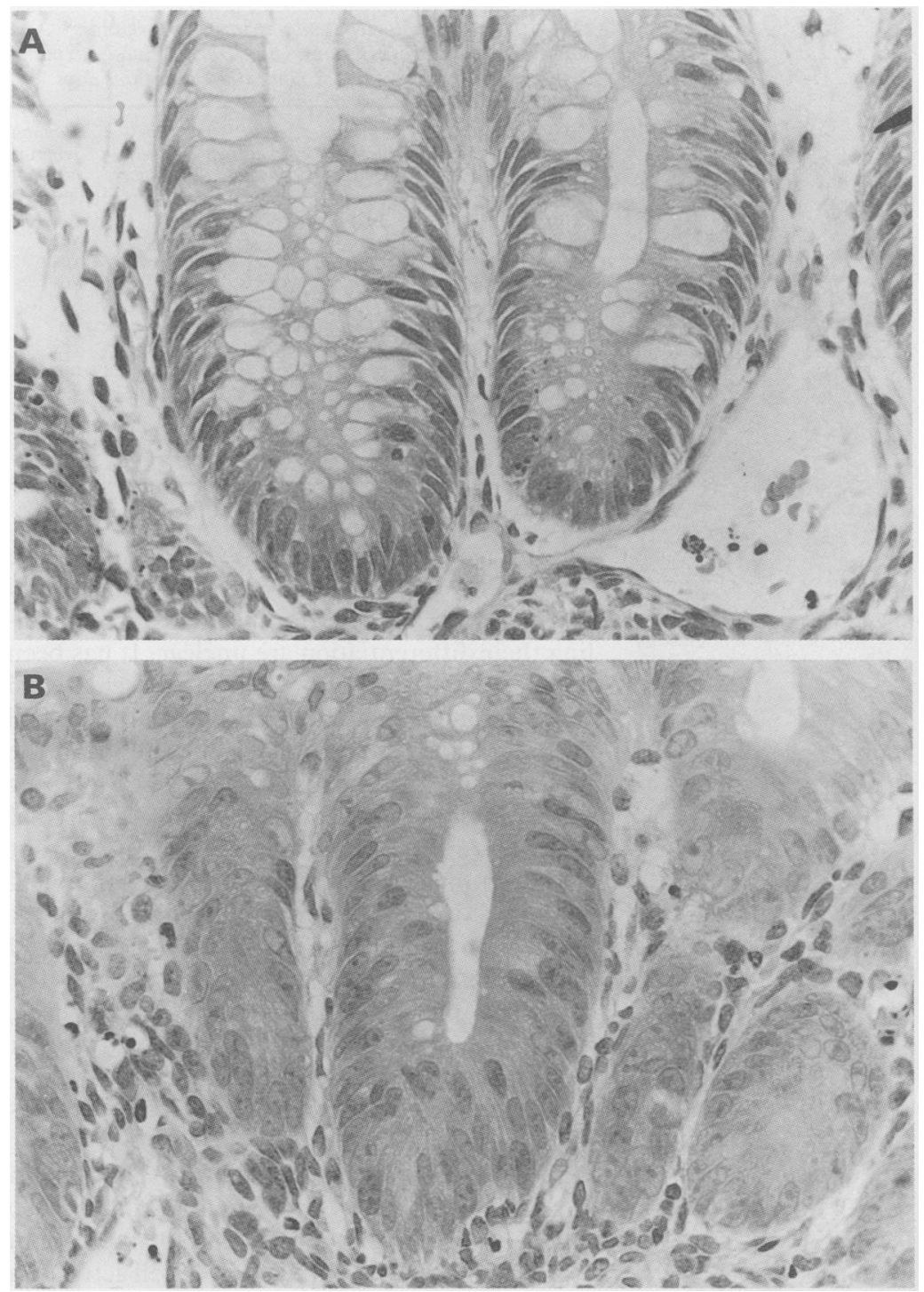

Figure 3: Morphological appearance of the mucosa of 20 week gestation human fetal colon cultured for 72 hours in medium alone $(A)$ or with anti-CD3 monoclonal antibody $(B)$, showing marked depletion of crypt goblet cells in the anti-CD3stimulated explants $(H \mathcal{E} E$ stain). insufficient tissue was available for organ culture.

\section{CYCLOSPORIN A}

Addition of $10 \mu \mathrm{g} / \mathrm{ml}$ cyclosporin $A$ to the culture medium in three separate experiments $(18,20$, and 23 weeks gestation) successfully inhibited the appearance of CD25+ cells in both pokeweed and anti-CD3 stimulated explants, and prevented the associated crypt hyperplasia and goblet cell depletion. In addition, HLA-DR expression was suppressed to the level of day 3 control explants. Addition of $0 \cdot 1,1$, and $10 \mu \mathrm{g} /$ $\mathrm{ml}$ cyclosporin A to cultured explants of 23 weeks gestation inhibited the effects of $T$ cell activation in a dose related fashion (Table IV).

\section{Discussion}

We have previously shown that activation of $\mathrm{T}$ cells in the lamina propria of human fetal small intestine in organ culture results in crypt cell hyperplasia, villus atrophy and an increase in the number of mucosal lymphocytes. ${ }^{7-9}$ The consequences of $\mathrm{T}$ cell activation in human fetal colon have not previously been explored. Fetal colon is anatomically distinct from fetal small bowel as early as sixth week of embryonic gestation, and there are substantial differences in cellular morphology between colonic epithelium and that of the small intestine as early as the 12th week of gestation. ${ }^{1819}$

In the present study, we have shown the presence of mucosal $\mathrm{T}$ cells in human fetal colon by immunohistochemistry, and have carried out the first quantitative assessment of colonic $T$ lymphocyte ontogeny. In addition, our experiments show, for the first time, that specific activation of lamina propria $T$ cells in cultured explants of human colon results in an increase in crypt cell proliferation rate, goblet cell depletion, and thinning of the epithelium. These changes were directly related to the gestational age of the fetal tissue studied, and must be attributed to the direct consequences of $T$ cell activation as they were not observed in explants from specimens deficient of $\mathrm{T}$ cells $(<16$ weeks).

Of great interest is the striking goblet cell depletion which occurred within three days of culture in $\mathrm{T}$ cell activated explants. The mechanism by which this mucus depletion occurs is not clear, although immunologically mediated reactions have been shown to directly effect goblet cell function, and can precipitate mucus release..$^{20-23}$ The marked fall in the crypt goblet cell:epithelial cell ratio accompanying the rise in crypt cellular proliferation after $\mathrm{T}$ cell activation is also interesting. Both the columnar and goblet
Figure 4: Time course of the changes in the ratio of crypt goblet cells to crypt epithelial cell nuclei in cultured explants of human fetal colon after $T$ cell activation with pokeweed mitogen (seven specimens) or antiCD3 monoclonal antibody (three specimens). Data pooled from 10 separate experiments using colon of 16-20 weeks gestation. The vertical bars above and below the points relate to the $95 \%$ confidence interval about the mean/median.

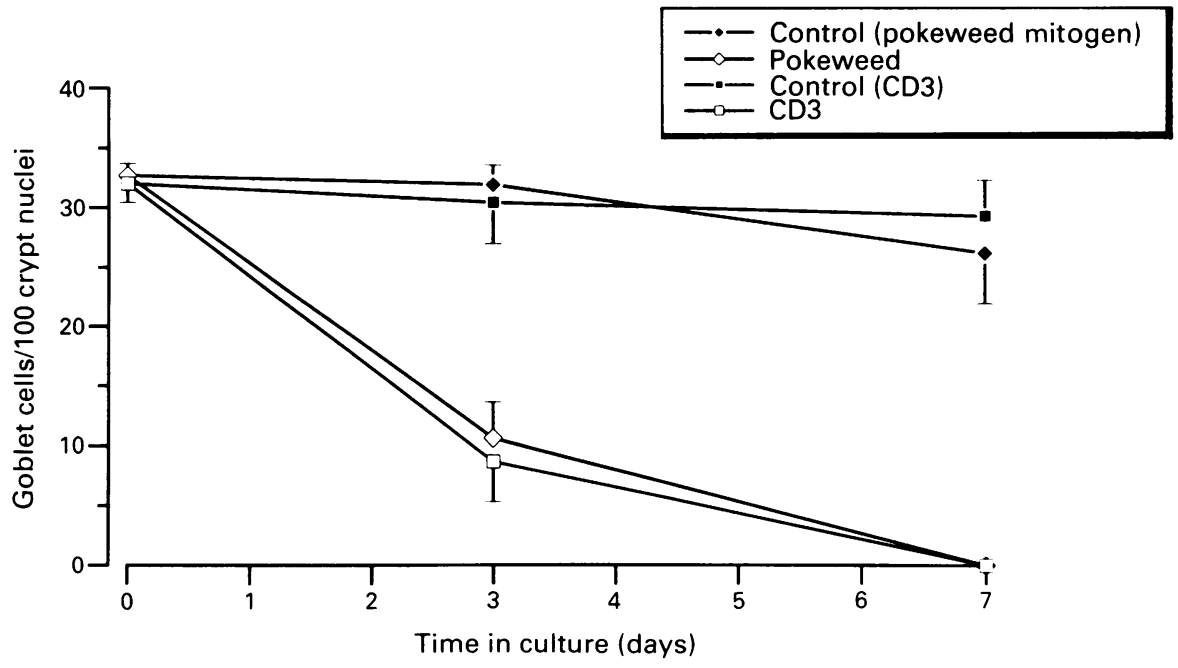



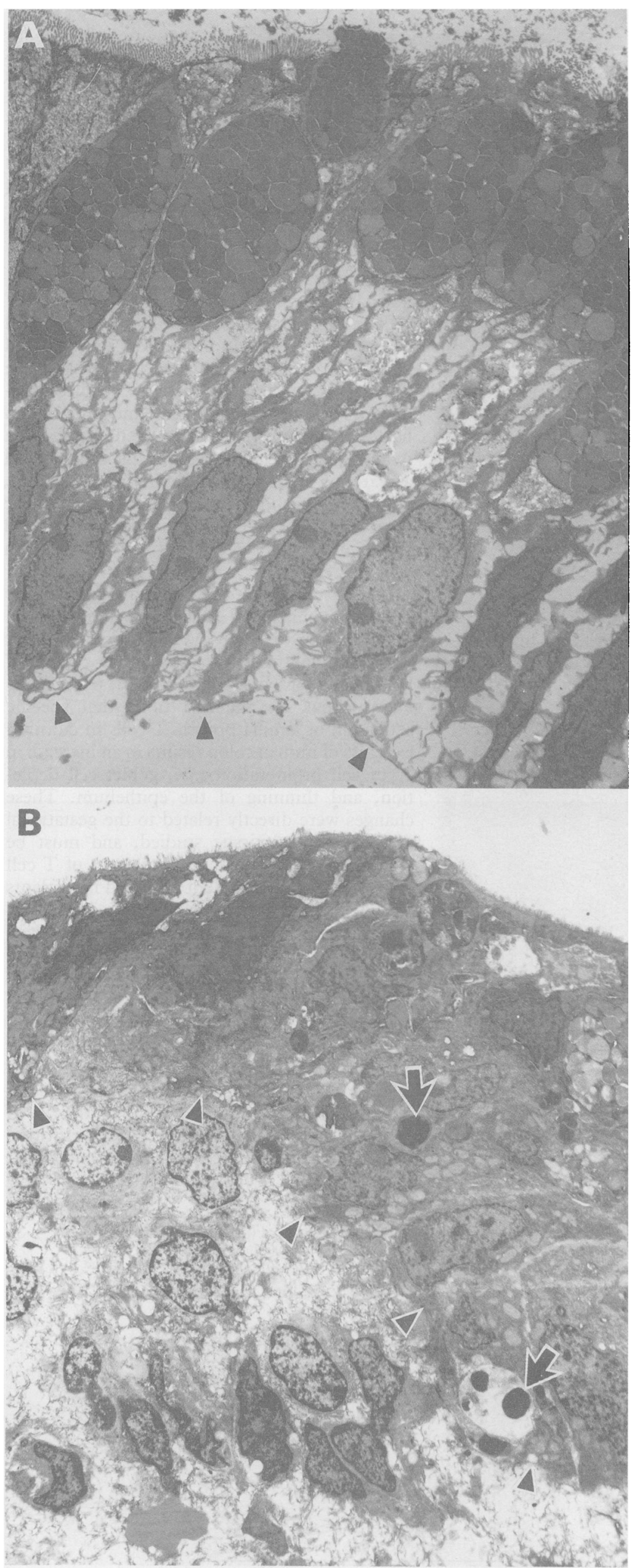

Figure 5: Electron micrographs of the surface epithelium of 22 week gestation human fetal colon cultured for 48 hours in medium alone $(A)$, or after $T$ cell activation on day $0(B)$. The position of the epithelial basement membrane is indicated in each (arrow-heads), as is the presence of anontosis (thick arrows) in the $T$ cell stimulated explants.
TABLE III Morphological and ultrastructural changes observed in the mucosa of control and $T$ cell activated explants from 22 week gestation fetal colon cultured for three days

\begin{tabular}{clllll}
\hline & $\begin{array}{l}\text { Crypt } \\
\text { depth }\end{array}$ & $\begin{array}{l}\text { Degree of } \\
\text { apoptosis }\end{array}$ & $\begin{array}{l}\text { Apical } \\
\text { cytoplasmic } \\
\text { vacuoles }\end{array}$ & $\begin{array}{l}\text { Inter- } \\
\text { epithelial } \\
\text { cell spaces }\end{array}$ & $\begin{array}{l}\text { Lamina } \\
\text { propria } \\
\text { oedema }\end{array}$ \\
\hline $\begin{array}{c}\text { Controls } \\
\text { Day 1 }\end{array}$ & + & - & yes & ++ & yes \\
Day 2 & + & - & yes & ++ & yes \\
$\begin{array}{c}\text { Day 3 } \\
\text { Pokeweed }\end{array}$ & + & - & yes & + & yes \\
Day 1 & ++ & ++ & yes & - & no \\
Day 2 & ++ & + & yes & - & yes \\
Day 3 & +++ & ++ & yes & - & no \\
Anti-CD3 & & & & & yes \\
Day 1 & ++ & + & yes & ++ & yes \\
Day 2 & ++ & ++ & yes & - & no \\
Day 3 & +++ & ++ & yes & - & no \\
\hline
\end{tabular}

cell lineages are believed to be derived from the same stem cell precursor in colonic and small bowel crypts, ${ }^{24-26}$ but the mechanisms controlling their differentiation are unclear. It has been suggested that in normal bowel, mesenchymal stimuli may play a role in crypt epithelial cell differentiation, ${ }^{27-30}$ possibly originating from the pericryptal myofibroblasts. ${ }^{31-33}$ The present study provides further evidence for mesenchymal influences on crypt epithelial cells. We cannot yet determine, however, whether the goblet cell depletion is caused by simple inhibition of maturation in this lineage, or whether stem cell differentiation has been redirected towards the columnar lineage. Our results do, however, support previous research which has shown that immunological mechanisms may effect enterocyte turnover and differentiation as well as physiological function. ${ }^{34} 35$

The mechanism by which the changes in epithelial morphology occur in this model is also intriguing. One possibility is that the increase in cellular proliferation induced by $\mathrm{T}$ cell activation results in a rapid migration of relatively immature, cuboidal cells from the crypt bases to the surface epithelium, which are more susceptible to shedding than mature cells. Second, the presence of apoptosis in both pokeweed mitogen and anti-CD 3 treated explants by day 3 shows that cell death was occurring, which may have resulted in the epithelial changes observed. Apoptosis must have been directly related to $T$ cell activation, as the phenomenon did not occur in control explants and was inhibited by cyclosporin A, and may have been mediated by the release of cytokines. This hypothesis is supported by the recent observation that human colonic mucosal $\mathrm{T}$ cells activated with anti-CD3 monoclonal antibody in vitro produce a combination of cytokines which are cytotoxic for the human colonic epithelial cell line HT-29. ${ }^{36}$

The effects of $T$ cell activation in cultured human fetal colon appear to differ from those previously reported in small bowel ${ }^{7}$ in two important respects. First, goblet cell depletion is not observed in mitogen treated small intestinal explants. This may reflect the fact that the greatly increased number of goblet cells in the colon makes any depletion which occurs more striking, although a careful histological comparison of $\mathrm{T}$ cell activated explants from small and large bowel suggested that this is not the case. Second, previous work has also failed to reveal evidence of epithelial thinning or cell damage 
TABLE IV Dose related effect of cyclosporin A on CD25+and Ki67+ cell counts per high power field (SD), goblet cell numbers and HLA DR expression in the mucosa of explants of 23 week gestation colon cultured for three days after the addition of cyclosporin $A(C y A)$ and antiCD3 monoclonal antibody

\begin{tabular}{lclll}
\hline & $\begin{array}{l}\text { CD25+ } \\
\text { cells }\end{array}$ & $\begin{array}{l}\text { Ki67+ } \\
\text { cells }\end{array}$ & $\begin{array}{l}\text { HLA DR } \\
\text { expression }\end{array}$ & $\begin{array}{l}\text { Goblet cell } \\
\text { depletion }\end{array}$ \\
\hline Day 0 specimen & 0 & $18 \cdot 7(2 \cdot 3)$ & + & None \\
Day 3 controls & 0 & $17 \cdot 3(4 \cdot 3)$ & + & None \\
Day 3 CyA 0.1 $\mu \mathrm{g} / \mathrm{ml}$ only & 0 & $18 \cdot 6(3 \cdot 7)$ & + & None \\
Day 3 CyA 1 $\mu \mathrm{g} / \mathrm{ml}$ only & 0 & $18 \cdot 5(3 \cdot 4)$ & + & None \\
Day 3 CyA 10 $\mu \mathrm{g} / \mathrm{ml}$ only & 0 & $19 \cdot 5(2 \cdot 3)$ & + & None \\
Day 3 Anti-CD3 Ab only & $29 \cdot 3( \pm 4 \cdot 1)$ & $50 \cdot 9(14 \cdot 1)$ & +++ & Severe \\
Day 3 Anti-CD3 Ab+CyA 0.1 $\mu \mathrm{g} / \mathrm{ml}$ & $23 \cdot 8( \pm 4 \cdot 5)$ & $35 \cdot 3(8 \cdot 4)$ & $++/+++$ & Mod-severe \\
Day 3 Anti-CDs Ab+CyA 1 $\mu \mathrm{g} / \mathrm{ml}$ & $13 \cdot 0( \pm 2 \cdot 7)$ & $26 \cdot 6(8 \cdot 1)$ & + & Mild-mod \\
Day 3 Anti-CD3 Ab+CyA 10 $\mu \mathrm{g} / \mathrm{ml}$ & $<1$ & $18 \cdot 7(3 \cdot 9)$ & + & None \\
\hline
\end{tabular}

$\star^{+}=$slight,$++=$moderate, $+++=$marked.

after $\mathrm{T}$ cell activation in cultured small bowel. ${ }^{9}$ These observations suggest that colonic epithelium does indeed differ substantially from that of the small intestine from early in fetal gestation, as previously reported. ${ }^{18} 19$

The histological abnormalities observed in this model are common to a number of disorders associated with inflammatory disease of the colon. Epithelial proliferation and goblet cell depletion are well recognised in the mucosa of patients with ulcerative colitis, ${ }^{37+40}$ and are particularly prominent during resolution of inflammation. Possible stimuli for these adaptive/ reparative responses have, until now, remained unclear. The results of the present study indicate that such responses can be mediated by activated lamina propria $T$ cells. This suggestion is supported by the fact that we have recently been able to show the presence of many CD25+ activated $\mathrm{T}$ cells in the mucosa of bowel resected from patients with active chronic inflammatory bowel disease. ${ }^{+1}$

This work was supported by the Crohn's in Childhood Research Association. T T MacDonald is a Wellcome Senior Lecturer. We wish to thank Dr Paul Richman for his helpful criticism of the manuscript, and the staff of the Samaritan's Hospital for Women for their help in providing the tissue.

1 Strober W, James SP. The immunological basis of inflammatory bowel disease. $\mathcal{F}$ Clin Immunol 1986; 6: 415-32

2 Elson CO. The immunology of inflammatory bowel disease. In: Kirsner JB, Shorter RG, eds. Inflammatory bowel disease Philadelphia: Lea \& Febiger, 1988: 97-164.

3 Brandtzaeg P, Halstensen TS, Kett K, et al. Immunobiology and immunopathology of human gut mucosa: humoral immunity and intraepithelial lymphocytes. Gastroenterology 1989; 97: 1562-84.

4 Entrican JH, Busuttil A, Ferguson A. Are the focal microscopic jejunal lesions in Crohn's disease produced by a T cell-mediated immune response? Scand f Gastroenterol 1987; 22: 1071-5.

5 Spencer J, MacDonald TT, Finn T, Isaacson PG. The development of gut associated lymphoid tissue in the terminal ileum of fetal human intestine. Clin Exp Immunol 1986; 64: 536 .

6 Spencer J, Dillon SB, Isaacson PG, MacDonald TT. T cell sub-classes in fetal human ileum. Clin Exp Immunol 1986; 65: 553-8.

7 MacDonald TT, Spencer J. Evidence that activated mucosal T cells play a role in the pathogenesis of enteropathy in human small intestine. $\mathcal{F}$ Exp Med 1988; 167: 1341-9.

8 Monk TJ, Spencer J, Cerf-Bensussan N, MacDonald TT. Activation of mucosal $\mathrm{T}$ cells in-situ with anti-CD3 antibody: phenotype of the activated $T$ cells and their distribution within the mucosal micro-environment. Clin Exp Immunol 1988; 74: 216-22.

9 da Cunha Ferreira R, Forsyth LE, Richman PI, Wells C, Spencer J, MacDonald TT. Changes in the rate of crypt epithelial cell proliferation and mucosal morphology induced by a $T$ cell-mediated response in human small intestine. Gastroenterology 1990; 98: 1255-63.

10 Autrup H, Barrett LA, Jackson FE, et al. Explant culture of human colon. Gastroenterology 1978; 74: 1248-57.
11 Menard D, Arsenault P. Explant culture of human fetal small intestine. Gastroenterology 1985; 88: 691-700.

12 Menard D, Arsenault P. Human fetal colon in organ culture. Anat Embryol 1987; 176: 441-8.

13 Isaacson PG, Wright DH. Immunocytochemistry of lymphoreticular tumours. In: Polak J, van Noorden S, eds. Immunocytochemistry. Practical applications in pathology and Immunocytochemistry. Practical applications in patholog

14 Phillips AD, France NE, Walker-Smith JA. The structure of the enterocyte in relation to it's position on the villus in childhood: an electron microscopical study. Histopathology 1979; 3: 117-30.

15 Hess AD, Colombani PM. Cyclosporin: mechanism of action: in-vitro studies. Prog Allergy 1986; 38: 198.

16 Campbell MJ, Gardner MJ. Calculating confidence intervals from some non-parametric analyses. In: Gardner $M J$, Altman DG, eds. Statistics with confidence - confidence intervals and statistical guidelines. London: BM7, 1989: 81-9.

17 Tomasini JT, Dobbins WO. Intestinal mucosal morphology during water and electrolyte absorption. Dig Dis 1970; 15: 226-38.

18 Menard D, Pothier P. Differential distribution of digestive enzymes in isolated epithelial cells from developing human fetal small intestine and colon. $\mathcal{F}$ Pediatr Gastroenterol Nutr 1987; 6: 509-16.

19 Pothier P, Menard D. Presence and characteristics of epidermal growth factor receptors in human small intestine and colon. FEBS Letts 1988; 228: 113-7.

20 Walker WA, Wu M, Bloch KJ. Stimulation by immune complexes of mucus release from goblet cells of the rat small intestine. Science 1977; 197: 370-2.

21 Lake AM, Bloch KJ, Neutra MR, Walker WA. Intestinal goblet cell mucus release. II. In vivo stimulation by antigen in the immunised rat. F Immunol 1979; 122: 834-7.

22 Lake AM, Bloch KJ, Walker WA. Anaphylactoid release of intestinal goblet cell mucus. Immunology 1980; 39: 1-6.

23 Neutra MR, O'Malley LJ, Specian RD, et al. Regulation of intestinal goblet cell secretion. II. A survey of potential secretagogues. Am 7 Physiol 1982; 242: G380.

24 Chang WWL, Leblond CP. A unitarian theory of the origin of the three populations of epithelial cells in the mouse large intestine. Anat Rec 1971; 169: 293.

25 Cheng $\mathrm{H}$, Leblond CP. Origin, differentiation and renewal of the four main epithelial cell types in the mouse small intestine. V. Unitarian theory of the origin of the four epithelial cell types. Am F Anat 1974; 141: 537-62.

26 Ponder BAJ, Schmidt GH, Wilkinson MM, Wood MJ, Monk $M$, Reid A. Derivation of mouse intestinal crypts from single progenitor cells. Nature 1985; 313: 689-91.

27 progenitor cells. Nature $1985 ; 313: 689-91$. Inductive properties of fibroblastic cell cultures derived from rat intestinal mucosa on epithelial differentiation. Differentiation 1983; 23: 226-33.

28 Lacroix B, Kedinger M, Simon-Assmann PM, Haffen K. Effects of human fetal gastroenteric mesenchymal cells on some developmental aspects of animal gut endoderm. Differentiation 1984; 28: 129-35.

29 Kedinger M, Simon-Assmann PM, Lacroix B, Marxer A, Hauri HP, Haffen K. Fetal gut mesenchyme induces differentiation of cultured intestinal endodermal and crypt cells. Dev Biol 1986; 113: 474-83.

30 Richman PI, Bodmer WF. Control of differentiation in human colorectal carcinoma cell lines: epithelial-mesenchymal interactions. I Pathol 1988; 156: 197-211.

31 Pascal RR, Kaye GI, Lane N. Colonic pericryptal fibroblast sheath: replication, migration and cytodifferentiation of a mesenchymal cell system in adult tissue. I. Autoradiographic studies of normal rabbit colon. Gastroenterology 1968; 54: 835-51.

32 Mathan M, Hermos JA, Trier JS. Structural features of the epithelio-mesenchymal interface of rat duodenal mucosa during development. F Cell Biol 1972; 52: 577-88.

33 Richman PI, Tilly R, Jass JR, Bodmer WF. Colonic pericrypt sheath cells: characterisation of cell type with new monosheath cells: characterisation of cell type with
clonal antibody. F Clin Pathol 1987; 40:593-600.

34 Castro GA. Immunological regulation of epithelial functions. Am f Physiol 1982; 243: G321-9.

35 Walker WA. Immunoregulation of small intestinal function. Gastroenterology 1984; 86: 577-9.
allation

36 Deem RL, Shanahan F, Targan SR. Triggered human mucosal $T$ cells release tumour necrosis factor-alpha and interferon-gamma which kill human colonic epithelial cells. Clin Exp Immunol 1991; 83: 79-84.

37 Morson BC, Dawson IMP. Gastrointestinal pathology. 2nd Ed. Oxford: Blackwell Scientific Publications, 1979: 523.

38 Serafini EP, Kirk AP, Chambers TJ. Rate and pattern of epithelial cell proliferation in ulcerative colitis. Gut 1981;22: 648-52.

39 Franklin WA, McDonald GB, Stein HO, et al. Immunohistologic demonstration of abnormal colonic crypt cell
kinetics in ulcerative colitis. Hum Pathol 1985; 16: 1129-32.

40 Allan A, Bristol JB, Williamson RCN. Crypt cell production rate in ulcerative proctocolitis: differential increments in rate in ulcerative proctocolitis: differential incre
remission and relapse. Gut 1985; 26: 999-1003.

41 Choy MY, Walker-Smith JA, Williams CB, MacDonald TT. Differential expression of CD25 (interleukin-2 receptor) on lamina propria $T$ cells and macrophages in the intestinal lesions in Crohn's disease and ulcerative colitis. Gut 1990; 31: 1365-70. 